\title{
Assets and Liabilities Management in Islamic Banking
}

\author{
Bijan Bidabad \\ B.A., M.Sc., Ph.D., Post-Doc. \\ Professor \\ Economics and Chief Islamic Banking Advisor \\ Bank Melli, Iran \\ E-mail:bijan@bidabad.com \\ Mahmoud Allahyarifard \\ Expert of R\&D Department \\ Bank Melli Iran \\ E-mail:allahyarifard@gmail.com
}

\begin{abstract}
Purpose: In this paper, we are going to consider assets and liabilities management (ALM) structure and instrument in Islamic banking. Since in Islamic banking depositors take partnership in benefits of the bank, so Islamic banking follows to maximizing benefits of beneficiaries and among them depositors. Therefore, there are dissimilarities between ALM approaches in Islamic banking and conventional banking. First, this dissimilarity comes from differences in the accounting system in Islamic banking in comparison to conventional banking. Secondly, usury illegalness and its related jurisprudence specifications indicate that time is not the solely the effective factor on increasing equity (deposited capital) return; but profit and loss sharing resulted from investment in the real economy sector is the essential base in monetary transactions. These two important factors are considerable factors in Islamic ALM.

Design/methodology/approach: we consider influence specifications of these factors in two banking approaches for creating Economic Value Added (EVA).

Findings: Comparison of financial indices for the two types of banking leads us that Islamic banking is more efficient than conventional banking.
\end{abstract}

Keywords: Islamic banking, ALM, Capital adequacy, Risk management

\section{Introduction}

Assets and Liabilities Management (ALM) consists of technical instruments and methods, which consider both value creation and controlling of risks for shareholders. Since one of the main duties of banks' financial management is ALM. Therefore, banks apply ALM techniques to increase more benefits by covering themselves from risks and minimize losses coming from transactions. The appropriate assessment of a bank's ALM requires a deep understanding of assets and liabilities, customers, economic environment, and competitive conditions of the bank. Thus prior to going through into Islamic banking respects of assets and liabilities, it is necessary to introduce Islamic banking assets and liabilities structures, market, customers, and other effective factors on ALM.

\section{Compatibility and incompatibility of economic theories with Islamic banking}

One of the main purposes of Islamic economics is real value added creation and social welfare maximization in the economy. On the other side, welfare economics, new business administration concepts, and also new international banking theories follow the value creation and maximizing of shareholders' benefits. Probably, one of the usury illegalness reasons in Islamic banking may come from the affection of money market fluctuation on a real economic sector that causes economic divergence from long-run stability growth and imbalances in money market and other markets as well. Therefore, the compatibility between conventional economics and Islamic economics theories can be observed, though this compatibility cannot be observed in all theories. The main contradictory between Islamic economics and conventional banking comes from usury illegalness principle, and usury and non-usury considerations on transactions are influenced by intellectual deduction of jurists, and Islamic economists and existence 
of contradictories among opinions in this realm are inevitable. Bidabad and Harsini $(2003)^{\mathrm{I}}$ by scrutinizing usury definition and using theosophy principal of jurisprudence defined some criteria to distinguish usury from non-usury transactions. It seems that these criteria may be accepted as an ending point of usury definition. The criteria are:

\begin{tabular}{|ll|}
\hline I. & Loaner must share in profit/loss of the economic activity of borrower. \\
2. & The rate of interest must not be determined and conditioned before. \\
3. & Interest in consumption loans is usury. \\
4. & Foreign currency exchange (without interest) is not usury. \\
\hline
\end{tabular}

Based on the above criteria, non-usury banking performance requires specific ALM approaches to make necessary coordination that applying those ALM techniques improve the efficiency and effectiveness of this type of banking. Islamic banking, as same as conventional banking follows maximizing shareholders assets but digressing that the real stakeholders of Islamic banks embrace all beneficiaries as depositors, investors, and business partners. The shareholder's assets are measured by the market value of shares, amount of payable profit, and also created value added. The share's market value or created value-added are affected by three factors: cash flows resulted from the financial ability of shareholders, cash flows' time scheduling, and risks of cash flows. The maximizing shareholder's equity in Islamic banking is considered by maximizing of value creation as well but must consider the principles of usury prohibition mentioned above. In this paper, Economic Value-Added (EVA) index will be considered as value creation criterion.

\section{Assets and Liabilities structures in Islamic banking}

The cognition of assets and liabilities structure in Islamic banking requires assets and liabilities items to be considered on the basis of Islamic Shariah.

Table I: General structure of assets and liabilities in Islamic banking

\section{ASSETS}

Cash and short-term funds

Deposits and placements with banks and other financial institutions

Short term investment (i.e., Sukouk)

Allowance for bad and doubtful financing

Financing and advances based on Islamic contracts

Direct investment

Other assets

\section{Fixed Assets}

Property, plant, and equipment

Other tangible assets

Intangible assets (i.e., goodwill)

\section{TOTAL ASSETS}

\footnotetext{
${ }^{\mathrm{I}}$ Bidabad, B. Harsini, A. (2003), Religious-economic analysis of usury in consumption and investment loans and shortages of contemporary jurisprudence in finding the rules of religion legislator. Monetary and Banking Research Academy, Central Bank of Iran, 2003. http://www.bidabad.com/doc/reba-en.pdf
} 


\section{Off Assets}

Customer commitment and contingencies

\section{LIABILITIES AND SHAREHOLDER'S EQUITY}

Deposits from customers

Deposits and placements of banks and other financial institutions

Bills and acceptances payable

Other liabilities

Provision for taxation and zakat

Ordinary share capital

Reserves

Shareholder's equity

TOTAL LIABILITIES AND SHAREHOLDER'S EQUITY

Bank commitment and contingencies

\section{Assets and Liabilities in Islamic Banking}

The source and origin of assets in Islamic banking same as conventional banking come from net benefit and liabilities. On the other words, the essential pillar of profit acquiring in Islamic banking is assets from internal sources of shareholder's equities and from an external source as liabilities. Productive assets in Islamic banking, which are classified as uses are affected by monetary resources and shareholders' equity or deposits of depositors which are categorized in Islamic contracts according to their liquidity degrees.

\section{Cash}

Similar to conventional banking, in Islamic banking, this type of assets is maintained for covering bank commitments. Low or lack of return of this type of assets and also its undesired effects of inadequate liquidity are very important for maintaining this type of assets. In other words, increasing losses of liquidity risk stimulated the Assets and Liabilities Committee (ALCo) to propose some guidelines to preserve the tradeoff between costs of maintaining liquidity and liquidity risk. Generally, optimum liquidity amounts to be maintained by the Islamic bank can be calculated by equation (I).

\section{I) $L R_{t}=\frac{A L_{t}+E L S_{t}}{E L N_{t}} \geq \sigma$}

$A L_{t}:$ Liquid assets

$E L S_{t}$ : Estimated acquired liquidity based on liability sources

ELN : Estimated liquidity needs

The above equation shows the optimum liquidity ratio, and it should be greater than $\sigma$ in absolute value. In Islamic banking, the required cash flow (ELN) variation is lesser than conventional banking. Because the rate of return in Islamic banking comes from rate of productivity in the real economy sector in correspondence to profit and loss sharing (PLS) mechanism and this will 
stabilize interest rate and loaning and depositing flows. According to figures (I) and (2), the rate of return and loans and deposits flows in Islamic banking are more stable than conventional banking. Figure (3) indicates liquidity risk curve shifts down (increases slope) in Islamic banking; thus, optimum liquidity in Islamic banking will be lesser than conventional banking.

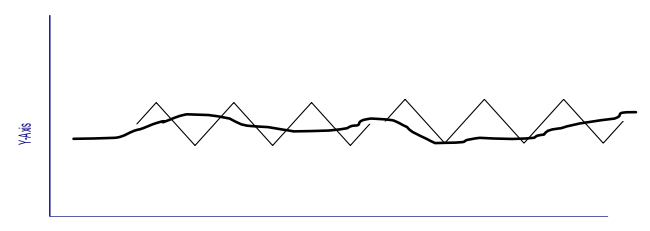

Figure1: Conventional banking

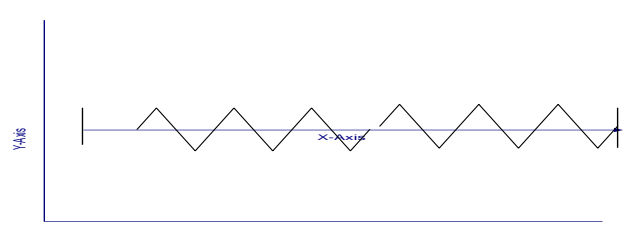

Figure 2: Islamic banking

Following figure (3), the optimum amount of liquidity can be calculated as the point of intersection of the cost of maintaining liquidity curve and the cost of insufficient liquidity curve in both types of banking. In other word, optimum liquidity measure is reached where liquidity costs are minimized as shown in the following figure.

Lower liquidity needs in Islamic banking will cause the liquid assets to be allocated for investment in high-return assets. Therefore, since the liquidity in Islamic banking is lesser than conventional banking, the opportunity cost for maintaining liquidity in Islamic banking is lesser than conventional banking as well. The liquidity needs in Islamic banking and conventional banking are shown with $b_{P L S}$ and $b_{C o n}$ parameters, and we can realize this relation: $b_{C o n}>b_{P L S}$.

\section{Trading off the cost of maintaining liquidity against the cost of insufficient liquidity}

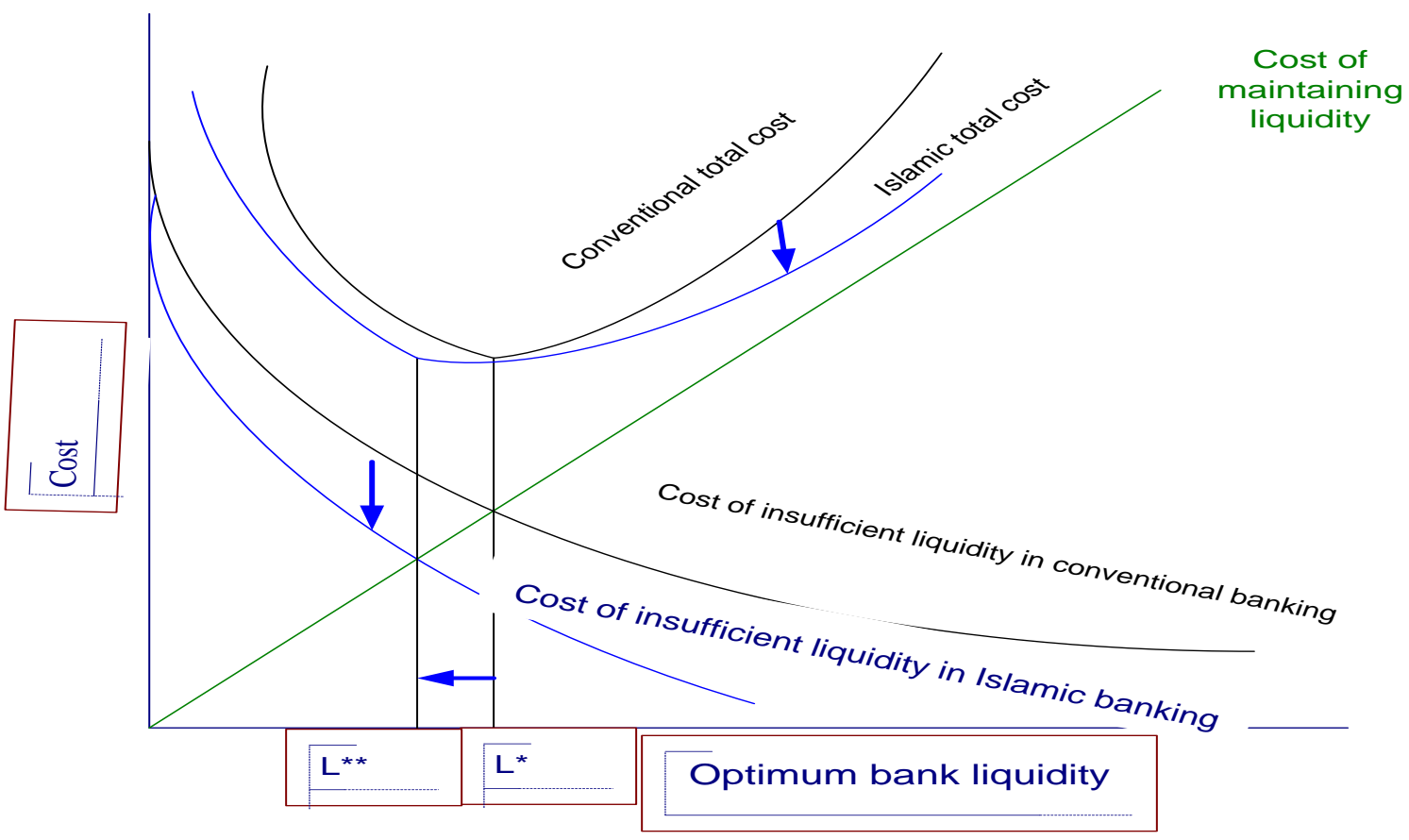




\section{High liquid Assets:}

Islamic banking may buy some return based assets instead of their cash hoardings. Despite being highly liquid, these assets have positive returns, and the bank can get profits of a joint venture in investment projects. Sukuk ${ }^{2}$ and Mosharekah bonds (Oragh-emosharakah) are samples of this type of assets in Islamic banking, which are replacements for bonds in conventional banking. The decision for maintaining this type of assets will be based on liquidity, inflation, rate of return of the real economy sector, and also economic conditions and regulations and etc.....

\section{Accounts and Notes Receivable}

The origin of this kind of assets comes from Islamic bank credit facilities as a form of debt buying (Kharid-e-Dayn) contraction. Purchasing of this type of assets will depend on customer credit position, rate of return, and economic conditions.

\section{Claims}

The banking claims include those purchased assets that go into the credit risk. Total outstanding claims, allowance for bad and doubtful financing of government and non-government claims, debts of paid L/C on the base of Islamic contracts, irrecoverable receivable notes, and others are classified in this group. The qualities of this type of assets regarding their returns in banks, whether Islamic or non-Islamic are different and depend on the type of collaterals, mortgage or non-mortgage and cash or noncash. So for calculating the allowances for bad debts and determining credit risk measure are considered by ALCO. The standard measure for allowances for bad debts (sum of public and specific reserves) to net loans should be at an acceptable level (the standard measure is $2 \%$ of net financing and advances). One of the advantages of Islamic banking in comparison to conventional banking is the transparencies of the balance sheet items. Because profit and loss sharing (PLS) will decline allowances for bad and doubtful financing. In the case of bankruptcy and investment loss, amounts of investment are directly booked in costs accounts, and therefore, the financial statement is more transparent in Islamic banking than conventional banking.

\section{Financing and advances based on Islamic contracts}

The main activity of financial intermediary institutions is credit loaning or financing and advances. In other words, financial intermediary institutions as economic firms are active in two markets. They demand financial resources from depositors (in deposit market), and on the other side, they supply credits to investors (in the credit market) ${ }^{3}$. Revenue of these institutions comes from differences between received and paid interest or interest premium. Prohibition of usury (riba) in Islam and other divine religions and also work and do as bases of value creation are main characteristics of Islamic banking products and services, so this type of banking tend toward Musharakah contracts with pre-undetermined profit/return rate.

Generally, selling assets as forms of credit products can be separable according to the following table 4 . Although, many of these products will enter into usury domain ${ }^{5}$, but are used by Islamic banks like Iran. In many Islamic countries which applying Islamic

\footnotetext{
${ }^{2}$ sukuk is a one of financing instruments which is based on Al-Ijareh contraction. Sukuk or Al-Ijareh negotiable paper can be issued on the bases of Al-Ijareh contractions basis and Al-Ijareh Muntahia Bittamlik. In the first type, Sukuks are issued and offered to borrow capital. The borrowed capital based on Sukuk is spend for buying capital intensive and durable goods on behalf of capital owners and the Sukuk's issuer by a leasing contracts rent the goods to customers who need these types of goods. At the end of duration of Ijareh, goods will be sold as scrap. The rent will repaid to Sukuk owners at the specified dates after deduction of costs. In the second type of Sukuk (Al-Ijareh Muntahia Bittamlik) at the end date of Ijareh contraction, the goods (Ain) by the way of gift (hibah), or at nominal price will be transferred to the lessee (Mostajer).
}

For more information see: Proceeding of the international new financial instrument on Islamic banking system conference, (2007), Export Development Bank of Iran, Tehran.

${ }^{3}$ See: Bidabad, Bijan, Mahmoud Allahyarifard, (2005), "IT role in fulfillment of profit and loss sharing" Proceeding of The $3^{\text {rd }}$ International Islamic Banking and Financing conference, Monash University, Kuala Lumpur, Malaysia. http://www.bidabad.com/doc/english-pls-5.pdf

${ }^{4}$ See: Hedayati, Aliaskhar, and co-authors, (2002), "Internal banking operation (2)", Iran Bank Institute, Central Bank of Iran, $5^{\text {th }}$ publish, p 9 (in Farsi).

${ }^{5}$ Bidabad, B. Harsini, A. (2003), Religious-economic analysis of usury in consumption and investment loans and shortages of contemporary jurisprudence in finding the rules of religion legislator. Monetary and Banking Research Academy, Central Bank of Iran, 2003. http://www.bidabad.com/doc/reba-en.pdf 
banking, PLS contraction has not developed deeply; for example, the PLS paradigm of Islamic banking in Malaysia has been much slower on the asset side than on the liability side. On the asset side, only $0.5 \%$ of Islamic bank financing is based on the PLS paradigm of mudarabah (profit-sharing) and mosharakah (joint venture) financing. ${ }^{6}$

Table I: Credit products in Islamic banking

\begin{tabular}{|c|c|c|c|c|c|}
\hline \multicolumn{2}{|c|}{ Gharzolhasanah } & \multicolumn{2}{|c|}{ Musharakah contractions } & \multicolumn{2}{|c|}{$\begin{array}{c}\text { Mobadelah (Exchangeable) } \\
\text { contractions }\end{array}$} \\
\hline Type of products & $\begin{array}{l}\text { Type of } \\
\text { return }\end{array}$ & Type of products & $\begin{array}{l}\text { Type of } \\
\text { return }\end{array}$ & Type of products & $\begin{array}{c}\text { Type of } \\
\text { return }\end{array}$ \\
\hline $\begin{array}{l}\text { Marriage, trousseau, } \\
\text { preparation, house } \\
\text { repairs, educational } \\
\text { allowance, subsidy for } \\
\text { rural constructions, and } \\
\text { other productive sectors }\end{array}$ & Flat rate & $\begin{array}{c}\text { Mudarabah (public, } \\
\text { specific), civil } \\
\text { Musharakah, legal } \\
\text { Musharakah, Direct } \\
\text { investment, Mozara'a, } \\
\text { Mosaghat }\end{array}$ & $\begin{array}{c}\text { Floating } \\
\text { rate }\end{array}$ & $\begin{array}{c}\text { Froush-Aghsati } \\
\left(\text { BBA }^{7}\right), \text { Ijareh- be } \\
\text { sharte- tamlik } \\
\text { Salaf (forward), } \\
\text { Kharid-Dayn (debt } \\
\text { buying), Jealah, } \\
\text { Istisna }\end{array}$ & Flat rate \\
\hline
\end{tabular}

In Iran, Islamic banking products can be separated into three major sectors of Gharzolhasanah, Mosharekah (joint) and Mobadelah (exchangeable) contractions. The banks are not authorized to receive profits from credit facilities based on Gharzolhasanah and just can get a commission based on the services they supply to their customers. The volume of this type of assets should be equal to the Gharz-al-hasanah resources. The return of Musharakah contracts should be determined on the base of activity in the real economy sector and to be determined according to profit and loss sharing (PLS) in investment. The return of Mobadelah contracts will be determined on the base of resale of assets to customers. There is no unanimity on these types of contracts regarding usury doubts. And the preferred contracts are those which are based on Mosharakah that Islamic jurisprudence unanimity exists among the jurists, though present supervision and accounting systems cannot monitor and cover the non-usury banking systems needs. ${ }^{10}$ Establishing of a secondary market for the certificate of deposit transactions in this type of investment, applying insurance of deposit instrument and transferring operational risk to depositors and also getting commission by the bank are of noticeable processes.

\section{Direct Investment}

Another item of assets is the investment of the Islamic bank in huge infrastructures developments projects. ${ }^{\text {II }}$

\section{Monetary resources for investment on the base of debt (deposits)}

The main debt items in non-usuric banks balance sheet are various deposits which customer of individuals or legal entities, private or public sectors have deposited at the bank. Generally, Islamic bank's deposits can be categorized into Gharzolhasan ah

\footnotetext{
${ }^{6}$ See: Beng Soon Chong, Ming-Hua Liu, 2007," Islamic Banking: Interest-Free or Interest-Based? ", www.efmaefm.org/OEFMAMEETINGS/EFMA\%20ANNUAL\%20MEETINGS/2007-Vienna/Papers/0019.pdf

${ }^{7}$ Bai- bithamin-ajil (BBA)

${ }^{8}$ Al-Ijareh Muntahia Bittamlik

${ }^{9}$ It is needed to notify that some economists believe that necessarily it is not needed to separate contractions as Gharzolhasaneh, Mosharekah, and mobadeleh; and some economists believe that Jealeh and Istesna can be classified into Mosharekah contracts.

${ }^{10}$ See: Bidabad, Bijan and mahmoud Allahyarifard, 2006 : Implementing IT to fulfill the profit and loss sharing mechanism, Islamic Finance News (IFN) Journals, 3 edition:. http://www.bidabad.com/doc/summery-pls-it-I.pdf This paper present a new method of Islamic banking. This method will be operational by use of profit and loss sharing (PLS) mechanism and by creating connection between deposits and investments projects. This project at the primary steps can be setup as pilot examination for short run construction and commercial investments as form of Mosharakah and mozarebah contractions.

${ }^{\text {II }}$ In case that these investments be governmental and its rate of return be less than rate of return of real economy sector, then the government should pay subsidy to the bank.
} 
and investment deposits. Gharzolhasanah deposits are cheap resources and include jari (current account), Pasandaz (saving account) which all of them are free of financial cost (payable interest). Another type of banking resources is investment deposits which Islamic bank can use them on the base of profit and loss sharing (PLS), and bank as intermediate agent apply them in different investment projects, and the investment return will be paid to depositors according to their proportions and durations. As a rule, all Gharzolhasanah deposits should be allocated to Gharzolhasanah loans.

\section{Capital}

Capital is the most important index for indicating how well the stability of a bank is. One of the international standards on the Basel Committee on banking supervision is the capital adequacy ratio (CAR). Capital adequacy ratio index comes from the sum of tier I or core capital and tier 2 or supplementary capital to risk-adjusted assets ratio (on the basis of Basel I is adjusted by credit risk and on the basis of Basel 2 is adjusted by credit, operational and market risk). This ratio for banks which they are members of the Basel Committee on banking supervision should be $\delta=8 \%$ as a minimum measure (see equation 2).

2) $C A=\frac{C 1+C 2}{R W A}>=\delta$

Structural differences between Islamic banking and conventional banking activities in economic activities viewpoint caused different theories regarding the way of calculating capital adequacy ratio in Islamic banking as follows:

- On profit and loss sharing (PLS) basis and lack of collaterals in this kind of transactions, Islamic banking face higher credit risk coefficients in comparison with conventional banks.

- In the PLS mechanism, depositors participate both in profit and loss which comes from the yield of investment, therefore calculating the risk coefficients of Islamic banks should be on the basis of proportions of depositors and bank. In other words, for calculating capital adequacy ratio, the weighted average of customer proportion of risk should be exited from the denominator of the fraction. Therefore the required capital adequacy ratio in Islamic banking is lesser than conventional banking.

- The other assets items in the balance sheet and off-balance-sheet items in Islamic banking like conventional banking posses different coefficient for operational, credit, and market risks.

\section{Economic value added (EVA) maximization in Islamic banking}

In non-usury banking, the monetary resources for investment come from two sources of debt capital and equity capital. The Islamic bank after deduction of legal reserves and provident funds by using the resources on the basis of Musharakah contracts (with floating profit) can invest them undividedly and distribute their returns on the basis of accrual accounting system among the stakeholders. The object of Islamic banking is to maximize the benefits of stakeholders, which include depositors and beneficiaries (legal owners).

In this section, by introducing economic value added (EVA) index as a value creation criterion, we will compare Islamic banking and conventional banking. Calculation of EVA is done by different methods of theoretical economics by reduction of the opportunity cost of capital from the net profit of the firm (after deduction of the taxes). Therefore in order to maximize the EVA, it is necessary to consider EVA in Islamic banking and conventional banking as:

3) $E \boldsymbol{V A}=\pi-\bar{r} \boldsymbol{K}$

$\bar{r}$ : weighted average cost of capital which is introduced as exogenous and follows the rate of return of the real economy sector; and $r_{P L S}$ is the rate of return in the real economy sector. Hence equation (3) is EVA, which $\pi$ is profit, and $\mathrm{K}$ is the capital of the Islamic bank. Rate of return in PLS mechanism is right the same rate of productivity, but the rate of return or 
interest rate in the conventional banking is equal to market interest rate plus the rate of risk. Therefore, rates of returns in the two systems can be compared by using the following relation:

$$
\text { 4) } r_{P L S}=r_{m}+E(d i v)
$$

According to equation 4, the rate of return on PLS basis is equal to the sum of market interest rate and mathematical expectation of a deviation term. This random deviation term contains credit risk as a negative factor and an unexpected return as a positive factor. Equality between real economy return rate and market interest rate will depend on this term. Therefore, three logical relationships could be written down as follows:

I) If $\mathrm{E}(\mathrm{div})=0 \rightarrow r_{P L S}=r_{C o n}$

If the mathematical expectation of the deviation term is equal to zero, then both rates will convergence to a unique rate.

$$
\text { II) If } \mathrm{E}(\mathrm{div})>0 \rightarrow \quad r_{P L S}<r_{\text {Con }}
$$

If the expected value of deviation increases, then the rate of return in PLS will be less than the conventional banking rate of return.

\section{III) If $\mathrm{E}(\mathrm{div})>0 \rightarrow \quad r_{P L S}>r_{\text {Con }}$}

If the expected value of deviation decreases, then the rate of return in PLS will be more than conventional banking.

The profit comes from differences between revenue and costs as equation (5):

5 ) $\pi=T R-T C$

The bank undivided revenue comes from disposable financial resources and commissions, and the revenue of non-credit products and services and is calculated by equation (6).

FD: disposable resources,

$r$ : rate of return of investment in the real economy sector.

6) $T R=F D r_{P L S}+B F$

The bank's disposable resource is calculated by equation (7).

$a$ : legal reserve ratio (received by the central bank for implementing monetary policies)

b: rate of the providential reserve or primary reserve for payment of short term bank commitments.

\section{7) $F D=D\left(1-a-b_{P L S}\right)$}

The bank cost is indicated by equation (8) and contains operational costs (OC) and non-operational costs (NOC). NOC includes personnel, administration and office and depreciation and amortization costs. OC includes expenses related to credit risk (allowances for bad and doubtful financing) and operational risk introduced as a proportion $(\theta$ ) of disposable resources for supplying credit facilities as shown by equation (9).

8) $T C=O C+N O C$

Generally, in Islamic banking on the basis of Musharakah contracts outstanding and expired due dated claims do not exist. Therefore $\theta$ coefficient in Islamic banking is lesser than this parameter in conventional banking. Based on the above discussion, 
this inequality holds: $\theta_{P L S}<\theta_{C o n}$.

$$
\text { 9) } O C_{P L S}=\theta_{P L S}\left(1-a-b_{P L S}\right) D
$$

Substitution of the above equations in EVA function of PLS will become:

10) $E V A_{P L S}=\left[D_{t}\left(1-a-b_{P L S}\right) r_{P L S}+B F_{t}-\theta_{P L S}\left(1-a-b_{P L S}\right) D_{t}-N O C_{t}-\bar{r} K_{t}\right]$

Operational costs of conventional banking are indicated by equation (II):

II) $O C_{C o n}=\left[\theta_{C o n}\left(1-a-b_{C o n}\right)+i\right] D$

$i$ : Weighted average of payable interest rate to depositors,

r: Weighted average receivable interest rate from loanee.

EVA function, in this case, will be as depicted by equation (I2)

12) $E V A_{C o n}=\left[D_{t}\left(1-a-b_{C o n}\right) r_{C o n}+B F_{t}-i D_{t}-\theta_{C o n}\left(1-a-b_{C o n}\right) D_{t}-N O C_{t}-\bar{r} K_{t}\right]$

The equations (I0) and (I2) indicate the EVA in the two banking approaches. According to the following reasons, we can deduce that EVA in Islamic banking is more than conventional banking.

- Since provident $\left(b_{P L S}\right)$ reserve in PLS banking is lesser than conventional banking $\left(b_{C o n}\right)$, so financial efficiency in PLS banking is more than conventional banking. The main reason for more efficiency is due to stability in cash flows of PLS banking; so for covering liquidity risk, less provident funds are required in comparison with conventional banking.

- Lack of outstanding claims and doubtful claims in PLS banking because of the nature of Musharakah contracts and supervision on investments decline $\theta_{P L S}$ coefficient in Islamic banking in comparison to conventional banking ( $\theta_{\text {Con }}$ ). Hence lack of this kind of inefficient assets will improve financial circulations in PLS banking than conventional banking, and this will grow up the EVA in this kind of banking system.

- Rate of return in PLS banking is more than the conventional banking $\left(r_{P L S}>r_{C o n}\right)$, so consequently EVA in PLS banking is higher than conventional banking.

Considering these three factors and parameters in the mathematical models and also logical and mathematical reasoning and analyzing them, we will conclude that the EVA in PLS banking will be more than conventional banking. For testing this hypothesis based on some case studies, we will have a look at the financial statements of Islamic RHB Bank and conventional bank from the same RHB bank comparatively.

\section{Comparison of financial indices in Islamic banking and conventional banking}

Table 2 indicates a quick ratio in two systems of PLS banking and conventional banking for the two approaches of RHB bank. The quick ratio indicated by $b$ is lesser in PLS banking than conventional banking, because of the stability of cash flows in PLS banking. Therefore declining of $\mathrm{b}$ coefficient is the main factor of increasing EVA in Islamic banking in comparison with conventional banking.

Table2: Comparison of liquid assets proportions in PLS and conventional banking 


\begin{tabular}{|c|c|c|c|c|}
\hline \multirow[t]{3}{*}{ Indices } & \multicolumn{2}{|c|}{ RHB Islamic banking } & \multicolumn{2}{|c|}{ RHB Investment banking } \\
\hline & 31.03 .2007 & 31.12 .2006 & 31.03 .2007 & 31.12 .2006 \\
\hline & & & $\mathrm{RM}, 000$ & \\
\hline $\begin{array}{l}\text { Cash balances with banks and other } \\
\text { financial institutions }\end{array}$ & 35035 & $2 \mathrm{I} 283$ & 35177 & 34147 \\
\hline Total assets & $823997 \mathrm{I}$ & 8092265 & 72675509 & 6834756 \\
\hline$Q R=\frac{\text { LiquidAssets }}{\text { Assets }}$ & $43 \%$ & $26 \%$ & $48 \%$ & $50 \%$ \\
\hline
\end{tabular}

Source: RHB Islamic Bank and RHB Investment Bank financial statements ${ }^{13}$

Table 3 will analyze another section of PLS banking characteristics. The decline of outstanding claims and allowance for bad and doubtful financing claims and more transparency of financial statements are other characteristics of PLS banking in comparison with conventional banking. According to table 3, allowances for bad and doubtful financing ratio to gross financing and advances (in PLS banking) and the same ratio to loans and advances (in the conventional banking) indicates this consequence. In PLS banking, because of characteristics of Mosharakah and Modarabah contracts, this ratio is lesser than conventional banking. This factor plays an important role to increase of EVA in comparison with conventional banking.

Table3: Comparison of allowances for bad and doubtful financing in PLS banking and conventional banking ( $\theta$ coefficient).

\begin{tabular}{|c|c|c|c|c|c|c|c|c|}
\hline \multirow[t]{3}{*}{ Indices } & \multicolumn{4}{|c|}{ RHB Islamic banking } & \multicolumn{4}{|c|}{ RHB Investment banking } \\
\hline & \multicolumn{2}{|c|}{$\begin{array}{c}\text { 3I.03.2007 } \\
\text { RM,000 }\end{array}$} & \multicolumn{2}{|c|}{$\begin{array}{c}\text { 3I.I2.2006 } \\
\text { RM,000 }\end{array}$} & \multicolumn{2}{|c|}{$\begin{array}{c}31.03 .2007 \\
\text { RM,000 }\end{array}$} & \multicolumn{2}{|c|}{$\begin{array}{c}\text { 3I.12.2006 } \\
\text { RM,000 }\end{array}$} \\
\hline & Amount & $\%$ & Amount & $\%$ & Amount & $\%$ & Amount & $\%$ \\
\hline Public & 78479 & 1.78 & 77059 & 1.8 & 13128 & 1.59 & I0432 & 1.38 \\
\hline Specific & 49374 & I.12 & 48822 & I.I4 & 63724 & 7.74 & 96458 & 12.72 \\
\hline Total & $\mathrm{I} 27853$ & 2.89 & $\mathrm{I} 2588 \mathrm{I}$ & 2.95 & 76852 & 9.34 & 106890 & I4.I \\
\hline $\begin{array}{l}\text { Gross financing and advances } \\
\text { or loans and advances, } \\
\text { RM,000 }\end{array}$ & 4416 & & 4273454 & & 823234 & & 758173 & \\
\hline
\end{tabular}

Source: RHB Islamic Bank and RHB Investment Bank financial statements ${ }^{\text {I4 }}$

Table 4 indicates some financial indices in PLS banking and conventional banking. These indices are shown in two groups of profitability and capital adequacy indices and will compare two different banking systems. The profitability indices include Return on Assets (ROA) and Return on Equity (ROE). According to this table, PLS banking profitability ratios are more than conventional banking. Higher ratios indicate higher efficiency and means higher EVA in PLS banking in comparison to conventional banking.

Capital adequacy ratio index has been calculated as advised by the Basel Committee on banking supervision standard in two banking systems. The first index is the core capital ratio (inclusive of market risk), which is calculated as Tier I capital ${ }^{15}$ to risk-

\footnotetext{
${ }^{12}$ Quick Ratio

13 http://www.rhb.com.my/about_rhb/financial/pdf/AC_31_Mar_07_final.pdf;
}

http://rhbislamicbank.com.my/pdf/RHBIB\%20Annual\%20Report\%202006_FinSec.pdf

${ }_{14}$ The mentioned same reference

${ }_{15}$ Tire 1 capital measures equity holding and is equal to the sum of tangible equity, including common stock, surplus, retained earnings, and perpetual preferred stock. Unlike primary capital under uniform rules, capital reserves are excluded from equity. See Donald R. Fraser and others, "Commercial banking and management of risk", 2001, South-Western College Publishing, pp. 398-399. 
adjusted assets ratio. The second index is calculated as an aggregation of Tier I capital and Tier 2 capital ${ }^{16}$ to risk-adjusted assets ratio.

According to table 4, the rate on assets (ROA) and rate on equity (ROE) in Islamic banking at the two considered times are more than conventional banking. Therefore, the mentioned relation $r_{P L S}>r_{C o n}$ indicates more return in PLS banking in comparison with conventional banking. As table 4 core capital ratio (including credit and market risk) and risk-weighted capital ratio (including credit and market risk) of conventional banking are more than Islamic banking. Applying the Basel Committee on banking supervision standards for calculating capital adequacy ratio (CAR) for the two approaches will cause higher CAR in conventional banking. Profit and loss sharing, a decline of risk coefficient, and transferring of a fraction of risk to depositors (in PLS mechanism) will increase CAR in Islamic banking. ${ }^{17}$ In other words, a decline of low-return-high-risk assets created by outstanding claims and doubtful financing or loans; change in risk coefficient based on Islamic standards, and transferring of a fraction of risk to depositors will increase CAR in Islamic banking in comparison to conventional banking.

Table4: Comparison of financial indices in PLS and conventional banking

\begin{tabular}{|c|c|c|c|c|}
\hline \multirow[t]{2}{*}{ Indices } & \multicolumn{2}{|c|}{ RHB Islamic banking } & \multicolumn{2}{|c|}{ RHB Investment banking } \\
\hline & $\begin{array}{c}31.03 .2007 \\
\% \\
\end{array}$ & $\begin{array}{c}31.12 .2006 \\
\% \\
\end{array}$ & $\begin{array}{c}31.03 .2007 \\
\% \\
\end{array}$ & $\begin{array}{c}31.12 .2006 \\
\% \\
\end{array}$ \\
\hline$\overline{\mathrm{ROA}}$ & .27 & $\mathrm{I} .07$ & .159 & .96 \\
\hline $\mathrm{ROE}$ & 3.28 & 13.25 & 1.64 & 9.24 \\
\hline $\begin{array}{l}\text { Core capital ratio (including of market } \\
\text { risk) }\end{array}$ & 17.36 & I7.78 & I8.5 & 20.29 \\
\hline $\begin{array}{l}\text { Risk-weighted capital ratio (including } \\
\text { market risk) }\end{array}$ & $\mathrm{I} 5.44$ & $\mathrm{I} 5.84$ & I4.6 & 16.02 \\
\hline
\end{tabular}

Source: RHB Islamic Bank and RHB Investment Bank financial statements ${ }^{18}$

\section{Summary and Conclusions}

Profit and loss sharing (PLS) banking characteristics will increase economic value added (EVA) as a value creation index in comparison with conventional banking. In this paper, the factors affecting economic value added regarding the aspects of assets items optimization, a decline of credit risk, and more transparency and also increase the rate of return were explained by applying different ALM indices. Lesser instability of financial flows and stability of PLS banking will decline liquid provident reserve for covering liquidity risk. On the other hand, releasing these types of assets and buying high return assets will increase EVA in Islamic banks. Profit and loss sharing characteristics and permanent supervision on investment are effective factors for removing or decreasing of outstanding claims, doubtful financing or loans, and more transparency of financial statements of PLS banking. Absence of these types of inefficient assets, safe and sound circulation of resources will increase the productivity of bank and will increase EVA on PLS banking. High financial stability and soundness in PLS banking will be accessible through higher return and lower risk. Comparison and study of financial statements in the two Islamic and conventional RHB banking approach made evidence for higher value-added creation of PLS banking. Another comparative evaluation of financial soundness of two banking approaches is the capital adequacy ratio. This ratio in PLS banking is higher than conventional banking due to the redefinition of risk coefficients, a decline of outstanding claims, doubtful financing or loans, change of quality of assets items from a risk point of view and increases of returns will increase CAR in PLS banking. Undoubtedly, the uniform calculation of Basel standards for all banks (Islamic and conventional) will create some deviations in fiscal comparison of different banks. In th is regard, international organizations and institutions like AAOIFI, IFSB, and also IDB will play an important role to introduce

\footnotetext{
${ }^{16}$ Tier 2 capital is comprised of loan loss reserves, subordinated debt, intermediate preferred stock, and other counted previously as primary capital (e.g., mandatory convertible debt and cumulative perpetual preferred stock with unpaid dividends). Refer to mentioned reference.

${ }^{17}$ In this way it will be necessary that international Islamic organization like IFSB or AAOIFI design evaluation and performance standards for Islamic banking for increasing Islamic banking interactions with other banks in the globe.

${ }^{18}$ Refer to the mentioned same reference
} 
these guideposts. Applying the standards provided by international institutions like the Basel Committee on banking supervision will be useful to increase the coordination of international banking with Islamic principles and usuric considerations.

\section{References}

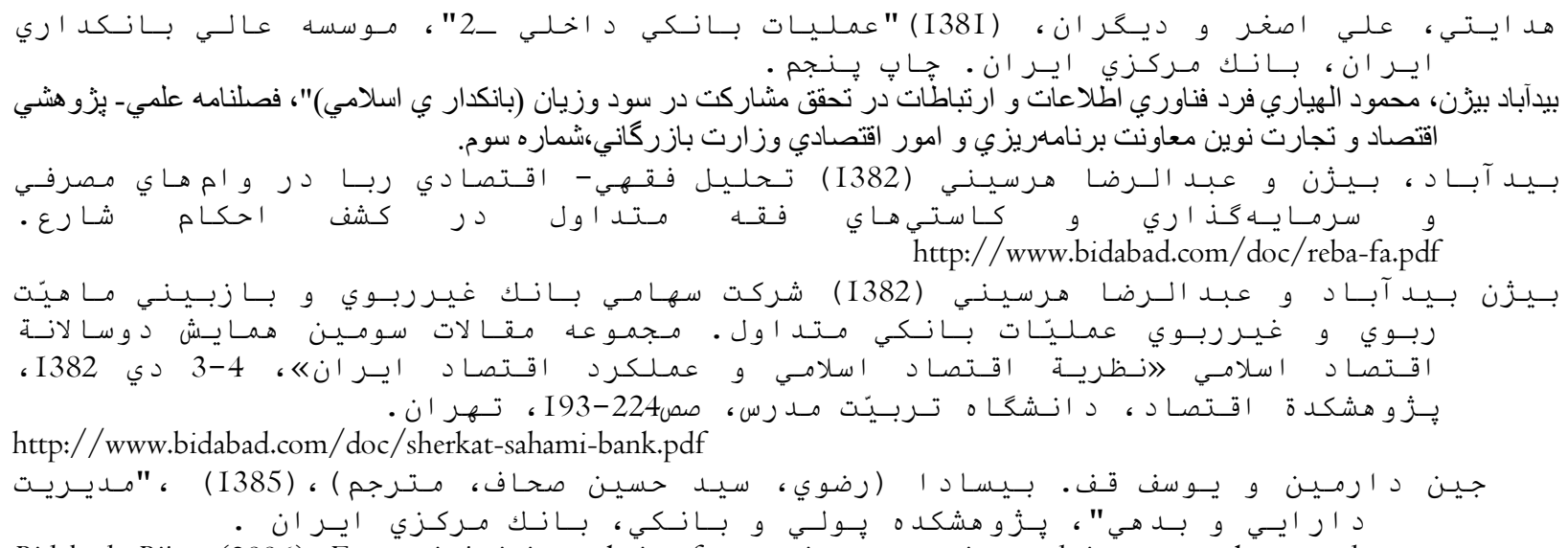

Bidabad, Bijan (2006), Economic-juristic analysis of usury in consumption and investment loans and contemporary jurisprudence shortages in exploring legislator commandments. Proceeding of the $2^{\text {nd }}$ International Islamic Banking Conference. The Monash University of Malaysia. 9-10 September 2004. Reprinted in: National Interest, Journal of the Center for Strategic Research, Vol. 2, No. I, winter 2006, pp. 72-90. Tehran, Iran. http://www.bidabad.com/doc/reba-en.pdf

Bidabad, Bijan (2005), Non-Usury Bank Corporation (NUBankCo), The Solution to Islamic banking, Proceeding of the 3rd International Islamic Banking and Finance Conference, Monash University, KL, Malaysia, I6-I7 November 2005. http://www.bidabad.com/doc/NUBankCo-en.pdf

Donald R. Fraser, Benton E. Gup, James W. Kolari, (200I), "Commercial banking the management of risk", South-Western college http://www.rhb.com.my/about_rhb/financial/pdf/AC_3I_Mar_07_final.pdf

http://rhbislamicbank.com.my/pdf/RHBIB\%20Annual\%20Report\%202006_FinSec.pdf

Bidabad, Bijan and Mahmoud Allahyarifard, (November 2005), "IT role in the fulfillment of profit and loss sharing", Proceeding of the $3^{\text {rd }}$ International Islamic banking and finance conference, Monash University, Kula Lumpur, Malaysia. http://www.bidabad.com/doc/english-pls-5.pdf

Bidabad, Bijan and Mahmoud Allahyarifard, (2006), "Implementing IT to fulfill the profit and loss sharing mechanism", Islamic Finance News (IFN) Journals, 3 edition: http://www.bidabad.com/doc/summery-pls-it-I.pdf.

Beng Soon Chong, Ming-Hua Liu, (2007)," Islamic Banking: Interest-Free or Interest-Based?", www.efmaefm.org/OEFMAMEETINGS/EFMA\%20ANNUAL\%20MEETINGS/2007-Vienna/Papers/O0I9.pdf

Proceeding of the international new financial instrument on Islamic banking system conference,( 2007), Export Development Bank of Iran, Tehran(in Farsi).

Hedayati, Aliaskhar, and other co-authors, (2002), "Internal banking operation (2) ", Iran Bank Institute, Central Bank Of Iran, 5th publish, pp 9 (in Farsi).

\section{Copyrights}

Copyright for this article is retained by the author(s), with first publication rights granted to the journal. This is an open-access article distributed under the terms and conditions of the Creative Commons Attribution license (http://creativecommons.org/licenses/by/4.0/). 